\title{
Danmarks og EU's fælles sikkerheds- og forsvarspolitik
}

Gorm Rye Olsen og Jess Pilegaard

På grund af forbeholdet om deltagelse i den fælles forsvars- og sikkerhedspolitik fremstår den danske politik inden for EU som usammenhængende og uforståelig - og dermed utroværdig

Dansk sikkerheds- og forsvarspolitik og dermed dansk udenrigspolitik har siden ophøret af den Kolde Krig været kendetegnet af to markante udviklingstræk. På den ene side har der gennem 1990'erne og ind i dette århundrede været en ganske stor beredvillighed til at anvende det militære kort ved at udstationere danske soldater i krise- og konfliktområder. På den anden side er den danske udenrigspolitik samtidig blevet stadig mere multilateraliseret, hvilket betyder, at Danmarks politik i stigende grad udformes i et tæt samspil med andre stater og internationale organisationer.

De to udviklingstendenser har manifesteret sig ved, at Danmark havde en fremtrædende placering $\mathrm{i}$ forbindelse med både FN's og NATOs militære indsatser i det tidli- gere Jugoslavien. Inden for rammerne af FN tog Danmark initiativet til at oprette en hurtig multilateral udrykningsstyrke kaldet SHIRBRIG, som første gang kom i aktion i forbindelse med en FN-overvåget våbenhvile mellem Eritrea og Etiopien på Afrikas Horn i år 2000.

Den iøjnefaldende udvikling viser ifølge forskeren Bertel Heurlin, at Danmark efter 1989 blev 'producent' af sikkerhed frem for som tidligere under den Kolde Krig at være 'forbruger' af sikkerhed. Lektor Steen Rynning fra Syddansk Universitet argumenterer på sin side for, at Danmark i løbet af 1990'erne ændrede sin internationale rolle fra at være en 'civil aktør' til i det nye århundrede at blive en såkaldt 'strategisk aktør'. Danmark var en civil aktør i kraft af, at man optrådte som 
tredjepart mellem to stridende parter, som det var tilfældet i eksempelvis Bosnien og Kosovo. Med den aktive danske deltagelse i det amerikansk ledede felttog i Afghanistan fra oktober 2001 er det imidlertid mere passende at beskrive Danmark som en 'strategisk aktør'.

Der er heller ingen tvivl om, at Danmark optrådte som strategisk aktør i forbindelse med det amerikansk ledede angreb mod Irak den 19. marts 2003, hvor man i lighed med situationen i Afghanistan stillede tropper til rådighed i forbindelse med de direkte kamphandlinger.

\section{Aktivistisk udenrigspolitik}

\section{Siden ophøret af den Kolde Krig} har skiftende danske regeringer været enige om, at en helt central målsætning for landets udenrigspolitik er, at Danmark skal spille en proaktiv rolle i den internationale politik. Der har også været enighed om, at en sådan ny 'aktiv internationalisme' skal bygge på de næunte to elementer nemlig udstationeringen af soldater, og at udstationeringen skal ske i et tæt samarbejde med andre lande inden for rammerne af forskellige institutioner. I 1993 offentliggjorde regeringen således en rapport om 'Dansk udenrigspolitik på vej mod år 2000', der slog fast, at EU og det politiske samarbejde EPS var "den vigtigste platform for Danmarks forhold udadtil".

Det er ikke en tilfældighed, at den
Europæiske Union i årene efter den Kolde Krig har udviklet sig til at blive det vigtigste multilaterale forum for formulering og implementering af dansk udenrigs- og sikkerhedspolitik i almindelighed. Danmark deltager således aktivt og konstruktivt i udviklingen af den fælles udenrigsog sikkerhedspolitik (FUSP).

Imidlertid står Danmark uden for samarbejdet om udvikling af en fælles europæiske forsvarspolitik (ESDP) på grund af en række undtagelser fra Maastricht-traktaten, som den danske regering opnåede i forbindelse med Det Europæiske Råds møde i Edinburgh i december 1992. I stedet for at samarbejde med EU udgør NATO, FN og på det seneste de såkaldte 'koalitioner af villige' derfor den organisatoriske ramme omkring de danske forsøg på at opnå international indflydelse ved hjælp af det militære kort.

Artiklen drøfter det stadig tydeligere dilemma, som Danmark som småstat står i som følge af sit bevidste valg af en ny proaktiv udenrigspolitik. Artiklen viser, at forbeholdet over for ESDP'en repræsenterer en stadig mere alvorlig blokering for at $\emptyset v e$ indflydelse på den internationale udvikling, som netop har været målet for de seneste 15 års danske udenrigspolitik. Det begrundes med, at Danmark på grund af sit forbehold over for det europæiske forsvarssamarbejde ikke kan udnytte den magtressource, der ligger i at deltage aktivt og fuldt ud i den sam- 
lede udvikling af den Europæiske Union. På grund af forbeholdet på et så vigtigt policy-område som forsvaret fremstår dansk udenrigs-, sikkerheds- og forsvarspolitik som usammenhængende og uforståelig og dermed utroværdig. Derved påvirkes de indflydelsesinstrumenter, som ligger i renommé, forhandlingsevne og diplomatisk manøvremulighed i negativ retning.

\section{Småstater og international indflydelse}

Småstater som Danmark er karakteriseret ved at besidde begrænsede fysiske ressourcer for så vidt angår BNP, militær magt og befolkningsstørrelse. I sagens natur har småstater begrænsede indflydelsesmuligheder, hvis de anvender sådanne ressourcer i international politik. Imidlertid kan små og mindre stater øve betydelig indflydelse ved at benytte 'bløde' eller ikke-fysiske magtressourcer som troværdighed, forhandlingsevne og viljestyrke.

Synspunktet er kort sagt, at småstater kan øve indflydelse, hvis den pågældende stat og dens forhandlere nyder respekt og har international troværdighed. Man taler i den forbindelse om, at stater har såkaldt 'koalitionsmagt', der defineres som "evnen til at danne eller operere som en indflydelsesrig deltager i vinderkoalitioner".

Staterne råder også over en vigtig ikke-fysisk magtressource ved at deltage $\mathrm{i}$ arbejdet og forhandlingerne $\mathrm{i}$ internationale organisationer. Internationale organisationer har den fordel, at de giver en struktureret ramme for udveksling af synspunkter mellem store stater og små stater. Deltagelse i sådanne organisationer sikrer, at synspunkter ikke alene vinder gehør på grund af medlemsstaternes fysiske magtressourcer. Staterne kan også øve indflydelse i kraft af troværdighed, forhandlingsevner og koalitionsmagt.

Nikolaj Petersen fra Århus Universitet understreger, at inden for den Europæiske Union repræsenterer dét at deltage aktivt og konstruktivt i integrationsprocessen i sig selv et vigtigt indflydelsesinstrument. Det følger heraf, at Danmarks manglende deltagelse i det forsvarspolitiske samarbejde gør det vanskeligt at bruge EU til at realisere målsætningen om at føre den proklamerede proaktive udenrigspolitik ved anvendelse af militære styrker.

Hvis man kombinerer ovenstående synspunkter, er det muligt at argumentere for, at en traditionel fysisk magtressource som militær magt under bestemte forudsætninger rent faktisk kan forbedre en småstats muligheder for at øve international indflydelse. Forudsætningen for at kunne udnytte det militære kort er for det første, at brugen fremstår forståelig og politikken troværdig for landets internationale partnere. Det betyder blandt andet, at der skal være en betydelig overensstemmelse mellem ord og hand- 
ling, hvis prestige, renommé og handlevilje skal kunne understøtte koalitionsmagt. For det andet skal en småstat som Danmark være i stand til at indgå i vinderkoalitioner og altså bruge sin koalitionsmagt.

Den følgende analyse af de danske indflydelsesmuligheder vil derfor først og fremmest fokusere på, hvorvidt det centrale indflydelsesinstrument 'koalitionsmagt' påvirkes positivt eller negativt af forsvarsforbeholdet. Derfor vil der blive gjort en del ud af at se nærmere på spørgsmålet om overensstemmelse mellem ord og handling.

\section{Sikkerheds- og forsvarspolitik}

Parallelt med at udstationeringen af militære styrker fik en stadig mere fremtrædende placering i dansk udenrigspolitik, skete der en markant udvidelse af det forsvars- og sikkerhedspolitiske samarbejde inden for den Europæiske Union. Maastricht-traktaten fra 1992 stadfæstede EU's ansvar for centrale sikkerhedspolitiske spørgsmål, herunder på sigt udarbejdelsen af en fælles forsvarspolitik som en integreret del af den Fælles Udenrigs- og Sikkerhedspolitik. Traktaten blev startskuddet til udviklingen af en ny identitet og nye opgaver for WEU, hvis medlemmer i juni 1992 vedtog erklæringen om de såkaldte Peterberg opgaver. De omfatter "humanitære operationer og redningsaktioner; fredsbevarende opgaver og op- gaver, der involverer kamptropper $\mathrm{i}$ krisehåndtering inklusive fredsskabelse". Det vil sige, at WEU og senere EU i princippet råder over hele spektret af militære krisestyringsinstrumenter lige fra de 'lette' til de 'tunge opgaver'.

Ligesom sammenbruddet af det tidligere Jugoslavien i begyndelsen af 1990'erne var en afgørende bevæggrund for at etablere FUSP'en, kom den fortsatte uro på Balkan og i særdeleshed Kosovo-konflikten i foråret 1999 til at understrege behovet for, at den Europæiske Union blev i stand til at påtage sig ansvaret for sikkerheden i sit eget nærområde. På det Europæiske Råds møde i Køln i juni 1999 besluttede man derfor at sætte Petersberg øverst på ESDP-dagsordenen.

Målet var at gøre EU i stand til at handle som en sikkerheds- og forsvarspolitisk aktør inden for rammerne af FN-systemet. På Helsinkitopmødet i slutningen af 1999 vedtog Rådet bl.a., at EU-landekredsen inden udgangen af 2003 skulle være i stand til at sende op mod 60.000 soldater i felten i op til 12 måneder med kun 60 dages varsel. Udrykningsstyrken skulle være i stand til at løfte hele viften af Petersberg-opgaver.

På den anden side var det helt klart, at EU-initiativet ikke betød, at der blev dannet en 'EU-hær', som traditionelt har været en dansk frygt over for ESDP'en. Topmødet understregede, at de nye strukturer skulle 
ses som komplementære til NATOsamarbejdet. Forsvar i tilfælde af en væbnet aggression udefra lå fortsat helt og holdent i NATO-regi. ESDPsamarbejdet skulle udvikles i samarbejde med NATO, hvilket afspejles i beslutningen om at lade europæiske NATO-medlemmer, som ikke er medlemmer af EU, deltage i eventuelle militære operationer.

De europæiske forsvarsministres beslutning i april 2004 om at oprette såkaldte 'battle groups' er en anden væsentlig udvikling af ESDP'en. Kampgrupperne skal være på ca. 1500 soldater med støtteelementer og skal kunne deployeres med kort varsel (15 dage). Målsætningen er at have 2-3 kampgrupper på plads inden udgangen af 2005 og yderligere 5-6 inden udgangen af 2007.

Alle EU-lande kan i princippet bidrage til disse kampgrupper. Set fra et dansk perspektiv er det interessant, at Norge som ikke-medlem af EU sammen med Finland og Sverige har etableret en EU-kampgruppe. Der kan således konstateres en markant udvikling af EU's fælles udenrigspolitik og fælles forsvarspolitik siden de tidlige 1990'ere. Der kan også iagttages ganske betydelige paralleller mellem udviklingen af dansk sikkerheds- og forsvarspolitik og udviklingen af ESDP'en.

\section{Det danske forbehold}

Ved topmødet i Edinburgh i december 1992 fik Danmark mulighed for at tage forbehold over for samarbejdet i EU omkring udarbejdelsen af en fælles forsvarspolitik. Forbeholdet er i øvrigt blevet fortolket af de skiftende regeringer på den måde, at der ikke anses at være noget til hinder for, at Danmark kan deltage i behandlingen i Råds-regi af forslag til afgørelser og aktioner, der har indvirkning på forsvarsområdet.

Regeringen har i forbindelse med drøftelserne om at styrke den europæiske forsvarsdimension henvist til, at det principielt kun er vedtagelsen af formelle retsakter med indvirkning på forsvarsområdet, som falder ind under forbeholdet. Regeringen har blandt andet deltaget i drøftelserne og har i øvrigt også tilsluttet sig udtalelser om emnet.

Op til møderne i Det Europæiske Råd i Helsinki i december 1999 og i Lissabon i marts 2000 valgte regeringen at henvise til forbeholdet. Derved ønskede man at markere, at udmøntning af disse vedtagelser måtte forventes at berøre forbeholdet. Helsinki-beslutningen blev fulgt op af en dansk beslutning om trods forbeholdet at deltage i arbejdet i de tre militærpolitiske organer, som skulle føre ESDP'en ud i livet.

I forbindelse med EU's såkaldte tilsagnskonference i oktober 2000, hvor en lang række lande inden for og uden for EU gav konkret tilsagn til den kommende EU-udrykningsstyrke, mødte den danske forsvarsminister, Hans Hækkerup, til gengæld frem uden at kunne stille trop- 
per til rådighed. Danmark kunne nok deltage i den overordnede tilrettelæggelse af ESDP, men man måtte afstå fra at medvirke til den konkrete udformning på det militære plan.

Samlet synes det danske forbehold frem til år 2003 primært at have haft symbolsk betydning. Selvom EU frem til 2003 kun havde foretaget mindre operationer i den bløde ende af Petersberg-opgaverne, er det ikke urimeligt at antage, at den danske politik ikke ligefrem styrkede Danmarks troværdighed som koalitionspartner.

Deltagelsen i behandlingen i Råds-regi af forslag til afgørelser og aktioner og den samtidige ikke-deltagelse i vedtagelsen af formelle retsakter må forekomme andre medlemslande uforståelig og inkonsekvent. Det samme indtryk efterlader deltagelsen i de tre militærpolitiske organer til implementering af ESDP'en, samtidig med at Danmark ikke ville stille soldater til EU's udrykningsstyrke.

Den følgende gennemgang af EU's militære krisestyringsoperationer skal tjene til at vise, at Danmarks forbehold over for sådanne opgaver blev mere og mere vanskelig at forstå for udenforstående. Det påvirkede uden tvivl landets koalitionsmagt negativt. Samtidig skal gennemgange vise, at både mål og implementering ligger klart og utvetydigt inden for rammerne af den proaktive danske udenrigs- og forsvarspolitik.

\section{Operation 'Concordia'}

Den 31. marts 2003 lancerede EU sin første militære mission nogensinde. Den fik kodenavnet 'Concordia' og fandt sted i Makedonien. EU-styrken skulle bidrage til at sikre gennemførelsen af den såkaldte Ohrid-aftale fra august 2001, der bilagde den truende konflikt mellem slavere og albanere i den tidligere jugoslaviske republik Makedonien. Det er vigtigt at understrege, at operationen blev gennemført efter anmodning fra den makedonske regering. Det kan ligeledes fremhæves, at den blev gennemført på baggrund af en FN-resolution.

EU-tropperne overtog opgaven fra NATO, som havde haft ansvaret for, at Ohrid-aftalen blev overholdt. EU-soldaterne skulle afpatruljere den etnisk albanske del af Makedonien, som grænser op til Albanien, Serbien og Kosovo. 13 EU-medlemmer deltog, mens Danmark og Irland ikke var med. Hertil kom, at yderligere 14 ikke-EU-medlemmer stillede tropper til operationen. Selvom operation 'Condordia' fremstod som en EU-operation, trak Unionen på NATO-udstyr, kommandostrukturer og planlægningskapacitet under det såkaldte Berlin Plus-arrangement. Operationen var derfor samtidig en prøvesag for det strategiske samarbejde mellem EU og NATO omkring krisestyring.

På grund af forbeholdet over for forsvarssamarbejde i EU måtte Dan- 
mark trække sine tropper hjem fra Makedonien, da EU overtog den fredsst $\varnothing t t e n d e$ operation. Det er værd at notere sig, at man trak sine soldater hjem fra en fredsbevarende aktivitet, som var acceptabel, så længe den foregik i NATO-regi. Operation 'Condordia' blev afsluttet den 15. december 2003 og blev efterfulgt af en EU-politiaktion, der betød, at der blev udstationeret 200 politifolk. Da der nu var tale om en civil aktion, kunne Danmark atter deltage. Det skete i form af udsendelse af 6 danske politifolk.

Det synes ret klart, at der intet var til hinder for, at Danmark kunne have stillet soldater til rådighed for operation 'Concordia' - hvis blot EU ikke havde haft ansvaret. Der var tale om en klassisk fredsbevarende mission, som oven i købet havde en Sikkerhedsråds-resolution i ryggen.

Den manglende deltagelse må siges at være inkonsekvent bedømt i forhold til ønsket om at føre en proaktiv udenrigspolitik i et snævert samarbejde med eksisterende internationale organisationer og bedømt ud fra den officielle politik om at støtte FN.

Som følge deraf må det formodes, at den manglende deltagelse i EUoperationen i Makedonien påvirkede Danmarks koalitionsmagt negativt.

På den anden side skal man være forsigtig med at overvurdere konsekvenserne af dette enkeltstående tilfælde.

\section{Operation 'Artemis'}

Den 12. juni 2003 vedtog EU's ministerråd endnu en banebrydende resolution inden for rammerne af ESDP'en. For første gang nogensinde besluttede Ministerrådet at udsende en ren EU-militærstyrke i en krisestyringsoperation uden for Europa, nærmere betegnet i Congo.

Operationen fik kodenavnet 'Artemis', og det er vigtigt at understrege, at den fandt sted på grundlag af en FN-resolution. Det er også værd at bemærke, at operation 'Artemis' var den første fuldstændig selvstændige militære EU-operation om end med et massivt fransk troppebidrag. Operationen blev gennemført, uden at man betjente sig af NATO-faciliteter inden for Berlin Plus-aftalen.

Målet med operation 'Artemis' var at stabilisere sikkerhedssituationen i den urohærgede Ituri-provins i Den Demokratiske Republik Congo for at forbedre den humanitære situation i og omkring hovedbyen Bunia. Baggrunden for at iværksætte 'Artemis' var konkret, at den humanitære situation i provinsen var blevet hastigt forværret igennem nogen tid. Den stadig alvorligere sikkerhedssituation betød, at det var vanskeligt og farligt at bringe $n \varnothing d-$ hjælp frem til mange områder i provinsen. $\mathrm{FN}$-folk havde gennem mere end et år anmodet om at få forstærket FN's tilstedeværelse i Ituri. Mange iagttagere vurderede, at den genopblussede ekstreme og tilfældige 
vold kunne true den igangværende proces på nationalt plan, der sigtede mod at nå en forhandlet løsning på konflikterne i DRC.

I den situation anmodede FN's generalsekretær, Kofi Annan, om etablering af en koalition af villige nationer, der var parat til at gøre en ende på den humanitære katastrofe i Ituri. Koalitionen skulle samtidig sikre en overgangsløsning frem til det tidspunkt, hvor det var muligt at udstationere en slagkraftig FN-styrke i provinsen. Selvom Frankrig optrådte som såkaldt framework nation for operationen, bidrog en lang række EU-lande samt flere fremtidige EUmedlemmer til den samlede operation.

Set fra et dansk synspunkt er det særlig interessant, at det traditionelt neutrale Sverige stillede soldater til rådighed for indsatsen, der nåede op på næsten 2000 soldater i alt.

Målt i forhold til de erklærede mål var operationen en rimelig succes. Det var den i og med, at en række centrale mål blev opnået. For det første blev sikkerhedssituationen i Bunia forbedret markant. For det andet sikrede EU-soldaternes tilstedeværelse, at en stor andel af de mange flygtninge vendte tilbage til hovedbyen. Operation 'Artemis' var også en succes, for så vidt som EUtropperne kunne overdrage kontrollen til en regulær FN-styrke på en i forvejen aftalt dato.

Der var således intet i formålet og forløbet af operation 'Artemis', der gør, at Danmark ikke ville have kunnet deltage - hvis blot ikke EU havde haft ansvaret. Operationen blev ydermere gennemført med et klart FN-mandat. Det må forekomme uforståeligt for vore internationale partnere, ikke mindst i EU, at Danmark ikke stillede et blot symbolsk troppekontingent til rådighed. Det er derfor sandsynligt, at politikken i forbindelse med operation 'Artemis' havde en negativ virkning på den danske koalitionsmagt inden for EU.

Det er i hvert fald usandsynligt, at det har styrket Danmarks omdømme og forhandlingsmuligheder inden for EU, at man to på hinanden følgende gange har undladt at deltage i en type krisestyringsopgaver som Danmark traditionelt støtter.

Danmark tog oprindeligt i 1992 forbehold over for, hvad der på daværende tidspunkt kunne udlægges som konturerne af en 'EU-hær'. I løbet af de seneste år har EU imidlertid udviklet sig til en sikkerhedspolitisk aktør, som på afgørende punkter underst $\varnothing$ tter Danmarks erklærede udenrigspolitiske målsætninger. Det understreger afstanden mellem Danmarks ord og handlinger.

\section{EU-FN samarbejde om krisestyring}

På basis af de positive erfaringer fra operation 'Artemis' vedtog EU's ministerråd og FN's generalsekretær efterfølgende en fælles erklæring om et fremtidigt udvidet samarbejde 
mellem FN og EU omkring krisestyring især på Balkan og i Afrika. Hos FN synes der at være en klar erkendelse af, at en hastig udrykningsstyrke som den i Congo i sommeren 2003 rummer lovende perspektiver.

Ikke mindst i lyset af at FN traditionelt har haft store problemer med at samle troppestyrker, der hurtigt kan sættes ind i krisesituationer, har det været nødvendigt for organisationen at se sig om efter andre løsninger. EU og FN aftalte derfor, at der skulle etableres en fælles mekanisme til konsultation med henblik på at styrke koordination og samarbejde omkring fremtidig krisestyring i Afrika og på Balkan. Erklæringen understregede klart, at ansvaret for opretholdelse af international fred og sikkerhed ligger hos FN og hos Sikkerhedsrådet.

En uafhængig analyse af perspektiverne af et udvidet EU-FN samarbejde fremhæver, at begge organisationer vil have fordele af mere samarbejde og koordination af deres aktiviteter. "I forhold til de militære aspekter af krisestyring har FN mere brug for EU end EU har brug for FN. EU kan hjælpe FN på områder, hvor det mangler midlerne til at intervenere som for eksempel med hastig udstationering af soldater... FN kan til gengæld give EU legalitet og politisk legitimitet til dets operationer".

Endelig fremhæver analysen, at formaliseringen af samarbejdet mellem de to organisationer som en sidegevinst giver EU voksende indflydelse i FN og især inden for Sikkerhedsrådet.

Der er som nævnt intet omkring operation 'Artemis', der gør, at Danmark ikke ville kunne have stillet tropper til aktionen. Oven i købet ville det have kunnet styrket $\mathrm{FN}$, hvilket længe har været en officiel dansk målsætning. Ved at være en aktiv partner i EU's fredsbevarende aktiviteter kan Danmark ikke alene støtte FN. Man kan også styrke EU's indflydelse på verdensorganisationen.

Begge elementer må vurderes at understøtte Danmarks koalitionsmagt og dermed forbedre mulighederne for at føre en proaktiv udenrigs- og sikkerhedspolitik. Ved at stå uden for en operation som 'Artemis' i DRC svækker Danmark med andre ord sine muligheder for at føre en proaktiv udenrigspolitik.

\section{Operation 'Althea'}

I december 2004 påbegyndte den Europæiske Union sin hidtil største militære operation, da Unionen overtog ansvaret fra NATO for det fredsbevarende arbejde i Bosnien. EUFOR bestod af 7.000 soldater, som kom fra ikke mindre end 33 lande. Næsten alle EU-lande deltog med tropper, og en række neutrale lande som Finland, Irland og Sverige stillede soldater til rådighed.

Ifølge det britiske dagblad The Guardian var det "en konkret mani- 
festation af, hvorledes EU's spæde fælles udenrigs- and sikkerhedspolitik - der var rystet af uenighederne over invasionen af Irak - faktisk kan fungere i praksis". Baggrunden for operation 'Althea' var, at man på NATOs møde i Istanbul i juni 2004 blev enige om at afslutte operationen i NATO-regi på grund af den forbedrede sikkerhedssituation i landet.

EU's overtagelse af NATOs opgaver fandt sted på grundlag af en enstemmigt vedtaget resolution $\mathrm{i}$ FN's sikkerhedsråd. Resolution No. 1551 af 9. juli 2004 udtrykte således en meget positiv holdning til EU's intentioner om at engagere sig militært i Bosnien \& Herzegovina. Og da EU's ministerråd den 25 . november samme år tog den formelle beslutning om at lancere operation 'Althea' skete det atter på baggrund af en enstemmigt vedtaget resolution i Sikkerhedsrådet, der bemyndigede EU til en kapitel VII-aktion.

Selve den militære operation blev foretaget ved hjælp af støtte fra NATO og i overensstemmelse med Berlin Plus-aftalen. Selv om EU har den formelle kommando, var det en klar aftale, at EU og NATO ville samarbejde tæt, efter at EU overtog ansvaret for det fredsbevarende arbejde. Målet for missionen var at sikre den fortsatte overholdelse af de aftaler, parterne indgik i henhold til Dayton-aftalen fra 1995. Dayton-aftalen betød, at NATO-tropper med et betydeligt indslag af amerikanske soldater fik ansvar for at overvåge våbenhvilen mellem de stridende parter i krigen i Bosnien.

Danske soldater deltog i den NATO-ledede styrke. Det er dog værd at bemærke, at der var tale om en nydannelse i og med, at den operative ramme var NATO og ikke FN. De danske soldater blev imidlertid trukket hjem i 2003, da det stod klart, at EU skulle overtage NATOopgaven. Da EU i december 2004 overtog ansvaret for sikkerheden i Bosnien \& Herzegovina, var de danske soldater for længst ude af landet.

Operation 'Althea' markerer et nyt skridt i udviklingen af ESDP'en, hvad angår størrelse og ambition. På den baggrund må man konstatere, at Danmark i forhold til den europæiske udvikling adskiller sig på to klare punkter. For det første kan man på grund af forbeholdet ikke deltage i udviklingen af EU som leverandør af europæisk sikkerhed. Ikke desto mindre har Danmark stadig en rolle som underleverandør/ leverandør af 'blød sikkerhed'. For det andet kan man ikke deltage i aktioner, som man principielt billiger, og som har klar FN-opbakning, men hvor EU bærer ansvaret.

Begge forhold må være svære at forstå for vores nærmeste partnere og allierede inden for både $\mathrm{EU}$ og NATO. Mangelen på en konsistent dansk politik må derfor forventes at påvirke landets troværdighed negativt både som EU-partner og som NATO-medlem. Dermed skades landets koalitionsmagt. 


\section{Danmark i FN's sikkerhedsråd}

Der er ingen tvivl om, at målet for Danmarks aktive internationale engagement i årene efter den Kolde Krig har været at føre en proaktiv politik med henblik på at øve indflydelse på den internationale udvikling. Da Danmark i efteråret 2004 blev valgt som et af de 10 ikke-permanente medlemmer af FN's Sikkerhedsråd for årene 2005 og 2006, fik landet en helt unik mulighed for at forfølge disse målsætninger.

Et af de centrale - officielt - formulerede mål for Danmarks deltagelse i Sikkerhedsrådet er at arbejde for at forbedre FN's evne til krisestyring og for at sammentænke FN's forskelligartede indsatser. Ved hjælp af pladsen i Sikkerhedsrådet vil Danmark gøre en helt særlig indsats for Afrika og her især for de mange konfliktramte lande.

Sikkerhedsrådet bruger mere end $60 \%$ af sin tid på Afrika, og det anslås, at op $\bmod 80 \%$ af det personel, der er udsendt i fredsbevarende aktiviteter for FN, er udstationeret i Afrika. Ikke desto mindre har FN gennem de senere år oplevet voksende problemer med at rekruttere soldater hos medlemslandene til fredsbevarende operationer i Afrika. Her kan aftalen mellem EU og FN vise sig at blive et af de centrale instrumenter, der kan sikre soldater til krisestyringsoperationer i Afrika.

Mens Danmark sidder i FN's sikkerhedsråd, men også bagefter, kan der ikke være tvivl om, at man vil støtte ethvert seriøst forsøg på at stabilisere sikkerhedssituationen i Afri$k a$. Hvis EU i fremtidige situationer vil stille soldater fra sin hurtige udrykningsstyrke til rådighed for $\mathrm{FN}$, vil Danmark uden tvivl støtte et sådant skridt. På den anden side vil man ikke selv kunne stille soldater til sådanne EU-ledede operationer.

Den danske udenrigsminister Per Stig Møller har ganske præcist formuleret det danske problem i forbindelse med det danske medlemskab af FN's Sikkerhedsråd. "Vi kunne faktisk komme i den paradoksale situation, at Danmark én dag sidder i New York og anmoder EU om at udføre krisestyringsopgaver for FN. Men når vi den næste dag sidder i stolen i ministerrådet i Bruxelles, er vi nødsaget til afstå fra at være med til at efterleve den opfordring fra FN, som vi selv har været med til at beslutte i Sikkerhedsrådet. ...Forbeholdene forhindrer os helt konkret i at være med på en række områder, hvor EU tager ansvar for at møde de nye udfordringer, som også er vores: At skabe fred og sikkerhed i vores nærområder...”.

\section{Ønske om indflydelse}

Der er ingen tvivl om, at EU's rolle i forbindelse med konfliktstyring ligger inden for rammerne af, hvad Danmark traditionelt har engageret sig i. Det må derfor forekomme uforståeligt, at Danmark enten trækker sine soldater hjem, før EU overtager 
kommandoen, eller at Danmark end ikke overvejer at deployere soldater i sådanne krisestyringsopgaver.

Der kan næppe herske tvivl om, at denne politik skader Danmarks troværdighed. Den pågældende politik stiller et stort spørgsmålstegn ved Danmarks handlevilje. Hvis man hertil lægger de potentielle konsekvenser af den inkonsekvente politik inden for de snævre rammer af ESDP'en, har Danmark store problemer med at bruge sin koalitionsmagt i EU. Hvordan kan man deltage i drøftelserne om fremtidens ESDP, men ikke deltage i vedtagelsen af formelle retsakter?

Det må konkluderes, at forsvarsforbeholdet hæmmer mulighederne for at bruge et af de helt centrale instrumenter i nyere dansk udenrigspolitik nemlig udstationeringen af soldater til at øge Danmarks indflydelse inden for den Europæiske Union. Dermed hæmmer forbeholdet Danmarks muligheder for at realisere ambitionen om spille en proaktiv rolle i international politik.

Det er et problem, at forbeholdet sender et uklart og inkonsekvent signal til vores partnere om, at landet ønsker 'autonomi' samtidig med, at Danmarks policy-erklæringer og konkrete adfærd inden for EU generelt signalerer et klart ønske om 'indflydelse'.

Anvendelsen af det militære kort til at skaffe Danmark indflydelse kan som følge af forbeholdet kun finde sted inden for rammerne af FN,
NATO eller alternativt inden for en koalition af villige. Hvis EU påtager sig krisestyringsopgaver på vegne af FN, må Danmark melde fra. Det må vi, selvom vi på alle måder støtter formålet.

Så er der også dansk deltagelse $\mathrm{i}$ NATO-ledede operationer som den i Afghanistan eller i en amerikansk ledet koalition som den i Irak. Det kan ikke afvises, at deltagelse i den type operationer kan give dansk indflydelse på den internationale udvikling. Det vil i så fald være i Washington og ikke inden for den Europæiske Union.

Danmark kan dog stadig føre en international proaktiv udenrigspolitik inden for rammerne af den Europæiske Union, ikke mindst på de 'bløde' områder. Det sikrer muligvis en højere grad af autonomi på forsvarsområdet - Danmark kan frit vælge side fra sag til sag - men det svækker så afgjort Danmarks langsigtede indflydelse på den internationale udvikling.

Danmark kan - politiske intentioner til trods - ikke gøre alverden som selvstændig spiller. Inden for rammerne af ESDP'en har Danmark derimod en enestående mulighed for at være med til at forme udvikling af EU som en selvstændig leverandør af både hård og blød sikkerhed.

Gorm Rye Olsen er leder af afdelingen for Europa-studier på Dansk Institut for Internationale Studier, Jess Pilegaard er Ph.d. studerende samme sted. 